Associate professor Jelena Maksimović

Original scientific paper Teaching assistant Jelena Osmanović ${ }^{2}$

UDC: 371.38

University of Niš, Faculty of Philosophy

DOI: $10.17810 / 2015.82$

Serbia

\title{
REFLECTIVE PRACTICE AS A CHANGING FACTOR OF TEACHING QUALITY
}

\begin{abstract}
A teacher, as one of the main actors in the teaching process, has an assignment to work continuously on the improvement of his personal characteristics and professional competencies in order to improve the quality of teaching. In a modern school, teachers are challenged to constantly reflect on their work, on its advantages and flaws, and on what needs to be fixed - they are required to become reflective practitioners. Despite the fact that the concept of reflective practice is not present enough in school practice, it has been recognized as an important factor for improvement of the teaching quality, as it represents a continuous process which helps teachers to get rid of a routine behaviour. The focus of the research is on faculty professors, and the research goal is to find out how students perceive their professors' practice, or whether they recognize the reflective elements to be important for improvement of the teaching quality. Accordingly, the purpose of the research is to point out the need, the importance and the necessity of being a reflective practitioner, both during the planning and during the work itself, but also after its completion, since the purpose of reflective practice is to realize the advantages and the flaws of one's work in order to improve it.
\end{abstract}

Keywords: reflexive practice, reflexive teaching, reflexive practitioner, quality of teaching.

\section{Introduction}

A teacher, as one of the main actors of the educational process or more specific, of the teaching process, has important assignments which differ from those that marked the teachers' role in the past. Nowadays, their role is being changed. The teacher is no longer just a means for the transfer of knowledge, since he is in the centre of the teaching process. Now, students are becoming the subjects of the teaching process, and the teacher's role is to help, encourage, follow, direct and advise them. This way, he becomes the organizer, the coordinator, the motivator, the evaluator, the researcher and the reflective practitioner.

Reflective practice is a concept that should be brought into the practice of teachers in the future, as it is very important for its improvement. Reflections represent a process of thinking about one's practice before, during and after the concrete activities. This means that the teacher spends time in planning and thinking about what he wants to realize, and that he will also wander if he has been on the right track, what the advantages and the flaws are, what is

\footnotetext{
1 jelena.maksimovic@filfak.ni.ac.rs

2 jelena.osmanovic@filfak.ni.ac.rs
} 
good, and what could be better, what needs to be changed and improved. Such issues mark the work of reflective practitioners and they represent the key for introducing positive changes in the planning of the future activities. The teacher becomes more aware of the self and of what surrounds him/ her thanks to the reflective practice. He reflects on his personal characteristics, such as his beliefs, values and prejudices, and how these can affect his work. He becomes more open-minded with his colleagues and his students. He exchanges ideas, opinions and experiences in order to improve his practice.

Many important elements of the teaching process can be accomplished at a higher level, thanks to reflective practice which has been recognized as a changing factor of teaching quality. These elements are preparation and planning of teaching, its performance, guidance and course, the classroom climate, the discipline, as well as the evaluation of students' progress and self-evaluation - basic teaching skills. Thus, reflective practice becomes the trend and the necessity in the work oftoday's practitioners, especially teachers and professors whose work requires constant re-examination.

\section{The idea of reflective practice}

The idea of using the term reflection in the teaching context comes from the original meaning of this term - the imageseen when looking into a reflective surface such as a mirror (Akbari et al., 2008). This means that a reflective teacher should look into the mirror and reflect on his teaching. Reflections are concise, narrow investigations related to thoughts, memories and self-examination of one's own performance (Kayapinar, 2016). The simple meaning of reflection is to stop and to think about one's actions and thoughts (Akbari et al., 2008). It is the thinking process which engages the teacher in a systematic, rigorous and disciplined reflection about his professional practice (Vijaua Kumari, 2014). Reflection is a deliberate and conscious process that requires engagement of cognitive, emotional and physical abilities in critical thinking about the past, present and future (intended or planned) actions in order to learn, better understand and potentially improve future actions (Harvey et al., 2016). It is a meta-cognitive process which implies awareness of what an individual does and thinks about (mental conception), and it consists of deliberate, biographical and critical research of personal beliefs, thoughts and actions (Mena Marcos et al., 2009). The purpose of reflective practice is to better understand the situation, as well as to provide effective, applicable actions for improving one's own performance (Impedovo \& Khatoon Malik, 2016). Brookfield (2005) emphasizes that an effort to look at things from different perspectives stands in the centre of the reflection process.

Reflective practice includes: (1) continuous self-analysis and self-evaluation; (2) openness to different ways of working than those already established; (3) identification of quality practice examples; (4) openness to sharing experiences with colleagues; (5) willingness to change the pre-established plan depending on the students' reactions; (6) teacher's readiness for analyzing those beliefs which are the basis of his actions and which he has previously incorporated into his own practice, without re-examining them (Budevac et al., 2013). According to Bard (2014), teachers face many challenges in their practice, so reflective practice cannot be implemented without considering the context in which it takes place. Therefore, it is understandable that many teachers find it difficult to take advantage of reflective practice, since it requires time, also it can seem daunting to novice teachers and requires a high level of autonomy and self-esteem. 


\section{How does one achieve the reflective practice?}

Despite the fact that reflective practice is a complete systemic approach to teaching, there are some different procedures supporting it. One of them is thinking about one's own work by answering the questions about different aspects of teaching practice. The teacher asks himself questions about his actions during the class, why he behaved in a certain way, about students' and parents' feelings and reactions and also about his own feelings. There is also a possibility for a teacher to regularly write down things that are brought to his attention while working with students, by keeping a diary. By analyzing his notes, he becomes aware of his own preoccupations, beliefs, habits, dilemmas, difficulties and patterns of what is present and what is missing in his practice (Budevac at al., 2013). This kind of self-reflection helps the teacher to realize or to become aware of the purpose and the meaning of his profession, making it easier to deal with everyday frustrations, inner conflicts, posing questions, problem solving etc. (Larrivee, 2000).

The teacher can also become aware of his beliefs by "giving advice“, meaning that he is supposed to think about the advice he would give to his less experienced, „imaginary“ colleague. Implementation of action research enables shaping and sharing the experience, and using it more systematically is firmly linked to the re-examination of one's own practice. There is also an analysis of the recorded classes which enables observing the aspects of teaching that cannot be obtained by diaries or personal reports, since many things are happening at the same time during the class. The study of scientific and professional literature about learning and teaching can help a teacher to gain insight into the wider context of the teaching process, to become aware of his unreal expectations, not to attribute all the effects of teaching exclusively to his work, and to be informed when it comes to the new revelations in the field of learning and teaching. The teacher can also recall and analyze his own experiences from school, meaning that he has to recall how he felt in a certain teacher's class, what this teacher's qualities were, why he appreciated him or still appreciates him etc., which helps him to compare his work with the work of his teacher. Another strategy is having a discussion with the students about how they perceive the teacher, how they feel during the class etc. Except with the students, the teacher can also share experiences with his colleagues, because other teachers can play the role of 'critical mirrors' which can reflect the actions of the teacher himself. Discussions with colleagues contribute to: sharing experiences, developing new ideas about teaching, spreading examples of quality practice, developing teachers' pedagogical competencies, developing self-esteem, analyzing important aspects of teaching from different angles, collecting and using new literature sources etc. (Budevac et al., 2013).

\section{Who is a reflective practitioner?}

A teacher who takes a critical approach when reflecting about what happens in the classroom and about alternative means of achieving goals is a reflective teacher (Soisangwarn \& Wongwanich, 2014). Reflection is a continuous process and a teacher - reflective practitioner is one of the possible paradigms of lifelong learning and progressing. It is also a new conceptual and methodical approach based on improving the process of learning and teaching, and therefore, reflective practice represents the opposite of technical and rational (traditional) model of the practitioners' development. A reflective practitioner is an active individual who is testing solutions and different ways of working while searching for the solutions of current problems. He is typically reflective, open-minded, which is notable in the moment of readiness for rethinking his opinion. 


\section{The role of reflective practice in the improvement of teaching}

Besides the fact that reflective practice influences professional learning and development of teachers, as well as the introduction of positive changes in educational practice, it is also defined as a changing factor of teaching quality. Reflective practice explores the implications of all complex factors in order to improve and better understand the teaching process (Vijua Kumari, 2014).

Some of the skills that can be improved with the help of reflective practice are analysis and identification of weaknesses of one's teaching, creating effective strategies for its improvement, as well as shaping the activities with the aim to change the practice (Bilac, 2015). In order to improve the practice, class management requires a reflective leader, as well as reflective skills and means (action research), without concerning whether it takes place in a gym, science laboratory or a typical classroom (Ryan, 2007). Reflective practice contributes to professional development of teachers by encouraging them to search for the ways of managing the class and guiding the students (Soisangwarn \& Wongwanich, 2014). Besides that, Singh Gill (2014) states that reflective practice enables teachers to became aware of their students' emotions, to recognize their individual needs, and to develop strategies to regulate thinking. Reconsideration of one's own practice contributes to: improvement of their work, efficient exchange of professional experiences with their colleagues, realisation of the professional standards, development into an active teaching creator, monitoring of their professional development, greater orientation to their own and their students' activities, more objective consideration of the situations inside and outsideof the classroom, creation of an appropriate ambience in the classroom, avoiding of routine and saturation, gathering of the new ideas for the future work etc. Larrivee (2000) indicates that it is not easy to accomplish reflection during or at the same time with our activities in the classroom because it requires coordination of multiple tasks. Self-reflection usually requires taking a metaposition while taking our previous activities in consideration. Self-reflection increases the teacher's awareness, thus creating the ability to detect irregularities or imbalances. Efficient teaching requires continuous examination of one's beliefs and reconsideration of one's actions related to them.

\section{Methodology of research}

The subject of our research is the students' perception of reflective practice as a changing factor of teaching quality. While setting the tasks of our research, our focus has been on the teaching skills as indicators of the quality teaching. These tasks are designed based on the proposition of the teaching skills (the planning and preparation of the teaching, its performance, guidance and course, the classroom climate, the discipline, the evaluation of students' progress and self-evaluation) given by Kyriacou (2001). The research tasks are: (1) To examine the students' perceptions of the reflective practice as a changing factor of the teaching planning and preparation; (2) To examine the students' perceptions of the reflective practice as a changing factor of the teaching performance; (3) To examine the students' perceptions of the reflective practice as a changing factor of the teaching guidance and course; (4) To examine the students' perceptions of the reflective practice as a changing factor of the classroom climate; (5) To examine the students' perceptions of the reflective practice as a changing factor of the class discipline; (6) To examine the students' perceptions of the reflective practice as a changing factor of the evaluation of students' progress and selfevaluation. The methods used in the research are the method of theoretical analysis and the 
descriptive method. As a research technique we have used scaling conducted by using the instrument named RPCFTQ (The reflective practice as a changing factor of teaching quality) especially designed for the needs of the research and based on the characteristics of the basic teaching skills given by Kyriacou (2001) which we have linked to the elements of the reflective practice from the theoretical part of the paper. The research sample consists of 202 participants - students from Niš, Bor and Belgrade.

Table 1 - The sample structure considering the faculty

\begin{tabular}{|c|c|c|c|c|}
\hline Faculty & Frequency & $\begin{array}{c}\text { Percent } \\
\%\end{array}$ & $\begin{array}{c}\text { Valid percent } \\
\%\end{array}$ & $\begin{array}{c}\text { Cumulative percent } \\
\%\end{array}$ \\
\hline Faculty of natural sciences & 27 & 13.4 & 13.4 & 13.4 \\
\hline $\begin{array}{l}\text { Faculty of social and humanistic } \\
\text { sciences }\end{array}$ & 99 & 49 & 49 & 62.4 \\
\hline Technical faculty & 76 & 37.6 & 37.6 & 100 \\
\hline Total & 202 & 100 & 100 & \\
\hline
\end{tabular}

Our intention has been to include students from different types of faculties (faculty of natural sciences; faculty of social and humanistic sciences and technical faculty), because the faculty that students attend can shape their attitudes which means there may be some differences in students' perceptions.

Table 2 - The sample structure considering the year of studies

\begin{tabular}{|c|c|c||c|c||}
\hline Year of studies & Frequency & Percent \% & Valid percent \% & Cumulative percent \% \\
\hline \hline First & 56 & 27.7 & 27.7 & 27.7 \\
\hline \hline Second & 43 & 21.3 & 21.3 & 49 \\
\hline \hline Third & 15 & 7,4 & 7.4 & 56.4 \\
\hline \hline Fourth & 32 & 15,8 & 15,8 & 72,3 \\
\hline \hline Fifth/sixth/master & 56 & 27,7 & 27,7 & 100 \\
\hline \hline Total & 202 & 100 & 100 & \\
\hline
\end{tabular}

The sample includes students in all of the years of undergraduate studies, as well as students of master studies with the aim of examining the differences in their perceptions of reflective practice as a changing factor of the teaching quality.

\section{Results of research}

The following part of the research shows the results related to the differences in students' attitudes considering the independent variables - faculty and year of studies, which we have obtained by using the F-test. The items with no statistically significant differences in students' attitudes have been left out. 
Table 3 - The differences in students' perceptions of the reflective practice as a changing factor of teaching planning and preparation considering the faculty

\begin{tabular}{|c|c|c|c|c|c|c|}
\hline & Faculty & $\mathbf{M}$ & SD & F-test & df & $p$ \\
\hline \multirow{3}{*}{$\begin{array}{l}\text { The professor must be } \\
\text { well acquainted with the } \\
\text { scientific and professional } \\
\text { literature in order to set } \\
\text { appropriate and } \\
\text { understandable teaching } \\
\text { objectives }\end{array}$} & $\begin{array}{c}\text { Faculty of natural } \\
\text { sciences }\end{array}$ & 4.222 & 1.050 & \multirow{3}{*}{4.665} & \multirow{3}{*}{2} & \multirow{3}{*}{0.010} \\
\hline & $\begin{array}{c}\text { Faculty of social } \\
\text { and humanistic } \\
\text { sciences } \\
\end{array}$ & 4.576 & 0.743 & & & \\
\hline & Technical faculty & 4.237 & 0.764 & & & \\
\hline \multirow{3}{*}{$\begin{array}{l}\text { Noting down the } \\
\text { advantages and the } \\
\text { disadvantages after class } \\
\text { helps the professor in the } \\
\text { future work planning }\end{array}$} & $\begin{array}{c}\text { Faculty of natural } \\
\text { sciences }\end{array}$ & 3.815 & 1.241 & \multirow{3}{*}{8.258} & \multirow{3}{*}{2} & \multirow{3}{*}{$\begin{array}{c}0.00 \\
0\end{array}$} \\
\hline & $\begin{array}{c}\text { Faculty of social } \\
\text { and humanistic } \\
\text { sciences }\end{array}$ & 4.404 & 0.727 & & & \\
\hline & Technical faculty & 3.921 & 0.963 & & & \\
\hline \multirow{3}{*}{$\begin{array}{l}\text { The professor has to } \\
\text { follow students' reactions } \\
\text { in order to stimulate their } \\
\text { attention, interests and } \\
\text { activity in the working } \\
\text { plans for the future }\end{array}$} & $\begin{array}{c}\text { Faculty of natural } \\
\text { sciences }\end{array}$ & 4,185 & 1.145 & \multirow{3}{*}{10.398} & \multirow{3}{*}{2} & \multirow{3}{*}{$\begin{array}{c}0.00 \\
0\end{array}$} \\
\hline & $\begin{array}{c}\text { Faculty of social } \\
\text { and humanistic } \\
\text { sciences }\end{array}$ & 4.687 & 0.583 & & & \\
\hline & Technical faculty & 4.132 & 0.998 & & & \\
\hline
\end{tabular}

Table 3 shows the differences in students' attitudes towards the reflective practice as a changing factor of teaching planning and preparation considering the faculty. The obtained $M$ values show that the students generally agree with the presented items, but there are some differences considering the students' faculty. A statistically significant difference in the students' attitudes has been noted in the presented items, because of the value $p<0.005$ $(p=0.010 ; p=0.000$ and $p=0.000)$. The students of social and humanistic sciences mostly agree with the answers to the presented items and, if we look at the $M$ values $(M=4.576 ; M=4.404$ and $M=4.687$ ), we can conclude that generally they have answered with I agree.

Table 4 - The differences in students' perceptions of the reflective practice as a changing factor of teaching planning and preparation considering the year of studies

\begin{tabular}{|c|c|c|c|c|c|c|}
\hline & Year of studies & M & SD & F-test & df & $\mathrm{p}$ \\
\hline \multirow{5}{*}{$\begin{array}{l}\text { The professor must be well } \\
\text { acquainted with the scientific } \\
\text { and professional literature in } \\
\text { order to set appropriate and } \\
\text { understandable teaching } \\
\text { objectives }\end{array}$} & First & 4.161 & 0,889 & \multirow{5}{*}{3.245} & \multirow{5}{*}{4} & \multirow{5}{*}{0.013} \\
\hline & Second & 4.279 & 0,854 & & & \\
\hline & Third & 4.40 & 0,828 & & & \\
\hline & Fourth & 4.533 & 0,567 & & & \\
\hline & Fifth/sixth/master & 4.661 & 0.745 & & & \\
\hline \multirow{2}{*}{$\begin{array}{l}\text { Noting down the advantages } \\
\text { and the disadvantages after class }\end{array}$} & First & 3,76 & 1,027 & \multirow[t]{2}{*}{4.810} & \multirow[t]{2}{*}{4} & \multirow[t]{2}{*}{0.001} \\
\hline & Second & 4,023 & 0,963 & & & \\
\hline
\end{tabular}




\begin{tabular}{|c|c|c|c|c|c|c|}
\hline & Third & 4,46 & 0,743 & & & \\
\hline & Fourth & 4,313 & 0,780 & & & \\
\hline & Fifth/sixth/master & $\begin{array}{c}4.42 \\
8\end{array}$ & 0.806 & & & \\
\hline \multirow{5}{*}{$\begin{array}{l}\text { The professor has to follow } \\
\text { students' reactions in order to } \\
\text { stimulate their attention, } \\
\text { interests and activity in the } \\
\text { working plans for the future }\end{array}$} & First & 4,08 & 0,958 & \multirow[b]{5}{*}{5.942} & \multirow[b]{5}{*}{4} & \multirow[b]{5}{*}{0.000} \\
\hline & Second & 4,163 & 1,214 & & & \\
\hline & Third & 4,533 & 0,639 & & & \\
\hline & Fourth & 4,68 & 0,535 & & & \\
\hline & Fifth/sixth/master & 4.732 & 0.486 & & & \\
\hline
\end{tabular}

Table 4 shows the items with the statistically significant differences in students' attitudes towards the reflective practice as a changing factor of teaching planning and preparation considering the year of studies $(p<0.005)$. Despite the fact that the students generally agree with the presented items, their attitudes depend on the year of studies. For the first item, there is a difference between the students of the first year of studies and the students of the fifth/sixth year/master studies $(M=4.161 ; M=4.661)$; for the second item, there is a difference between the students of the first and the students of the third year of studies $(M=3.768$; $M=4.467)$, and for the third item, there is a difference between the students of the first and the fourth year of studies $(M=4.089 ; M=4.732)$. We can conclude that the majority of the respondents agree with the fact that the studying of literature, the cooperation with colleagues and students etc., is important for the teaching plan and preparation, which confirmed our hypothesis that 'It is assumed that the students think that reflective practice improves the teaching plan and preparation.'

Table 5 - The differences in students' perceptions of reflective practice as a changing factor of the teaching performance considering the faculty

\begin{tabular}{|c|c|c|c|c|c|c|}
\hline & Faculty & M & SD & F-test & df & p \\
\hline \multirow{3}{*}{$\begin{array}{l}\text { It is necessary for the professor to } \\
\text { follow the students' reactions to } \\
\text { make sure that his instructions and } \\
\text { interpretations are understandable } \\
\text { and appropriate }\end{array}$} & $\begin{array}{c}\text { Faculty of natural } \\
\text { sciences }\end{array}$ & 4.482 & 0.700 & \multirow{3}{*}{6.034} & \multirow{3}{*}{2} & \multirow{3}{*}{0.003} \\
\hline & $\begin{array}{l}\text { Faculty of social } \\
\text { and humanistic } \\
\text { sciences }\end{array}$ & 4.636 & 0.543 & & & \\
\hline & Technical faculty & 4.250 & 0.925 & & & \\
\hline $\begin{array}{l}\text { The discussion with students helps } \\
\text { the teacher to develop respect for } \\
\text { their ideas and to help them with }\end{array}$ & $\begin{array}{c}\text { Faculty of natural } \\
\text { sciences }\end{array}$ & 4.296 & 0.912 & 5.031 & 2 & 0.007 \\
\hline
\end{tabular}




\begin{tabular}{|c|c|c|c|c|c|c|}
\hline & $\begin{array}{l}\text { Faculty of social } \\
\text { and humanistic } \\
\text { sciences }\end{array}$ & 4.596 & 0.741 & & & \\
\hline & Technical faculty & 4.224 & 0.826 & & & \\
\hline \multirow{3}{*}{$\begin{array}{l}\text { Thinking about the students' feelings } \\
\text { and reactions helps the professor to } \\
\text { adjust the teaching to their needs }\end{array}$} & $\begin{array}{l}\text { Faculty of natural } \\
\text { sciences }\end{array}$ & 3.741 & 1.258 & \multirow{3}{*}{3.797} & \multirow{3}{*}{2} & \multirow{3}{*}{0.024} \\
\hline & $\begin{array}{l}\text { Faculty of social } \\
\text { and humanistic } \\
\text { sciences }\end{array}$ & 4.111 & 0.867 & & & \\
\hline & Technical faculty & 3.723 & 1.001 & & & \\
\hline
\end{tabular}

Table 5 shows the items with statistically significant differences in the students' attitudes towards reflective practice as a changing factor of the teaching performance considering the faculty, with the value $p=0.003 ; p=0.007$ and $p=0.024(p<0.005)$. The obtained $M$ values show us that the students have mostly given the answer I agree, but also that there are differences among them, considering the faculty they attend. The students of social and humanistic sciences show the highest degree of agreement in their answers to the research items $(M=4.636 ; M=4.596 ; M=4.111)$.

Table 6 - The differences in students' perceptions of the reflective practice as a changing factor of the teaching performance considering the year of studies

\begin{tabular}{|c|c|c|c|c|c|c|}
\hline & Year of studies & M & SD & F-test & df & p \\
\hline \multirow{5}{*}{$\begin{array}{l}\text { It is necessary for the professor } \\
\text { to follow the students' reactions } \\
\text { to make sure that his } \\
\text { instructions and interpretations } \\
\text { are understandable and } \\
\text { appropriate }\end{array}$} & First & 4.214 & 0,92 & \multirow{5}{*}{2.713} & \multirow{5}{*}{4} & \multirow{5}{*}{0.031} \\
\hline & Second & 4.535 & 0,735 & & & \\
\hline & Third & 4.400 & 0.910 & & & \\
\hline & Fourth & 4.562 & 0,56 & & & \\
\hline & Fifth/sixth/master & 4.643 & 0.519 & & & \\
\hline \multirow{5}{*}{$\begin{array}{l}\text { In order to encourage the } \\
\text { students' studying through } \\
\text { appropriate activities, the } \\
\text { professor has to explore } \\
\text { examples of a good practice } \\
\text { (effective, quality teaching) }\end{array}$} & First & 4.071 & 0.891 & \multirow{5}{*}{2.842} & \multirow{5}{*}{4} & \multirow{5}{*}{0.025} \\
\hline & Second & 4.279 & 0,701 & & & \\
\hline & Third & 4.200 & 0,67 & & & \\
\hline & $\begin{array}{ll}\text { Fourth } \\
\end{array}$ & 4.280 & 0,812 & & & \\
\hline & Fifth/sixth/master & 4.536 & 0.538 & & & \\
\hline \multirow{5}{*}{$\begin{array}{l}\text { The discussion with students } \\
\text { helps the teacher to develop } \\
\text { respect for their ideas and to } \\
\text { help them with the realisation of } \\
\text { those ideas }\end{array}$} & First & 4.000 & 0,89 & \multirow{5}{*}{6.218} & \multirow{5}{*}{4} & \multirow{5}{*}{0.000} \\
\hline & Second & 4.511 & 0.79 & & & \\
\hline & Third & 4.400 & 0,63 & & & \\
\hline & Fourth & 4.531 & 0,87 & & & \\
\hline & Fifth/sixth/master & 4.696 & 0.56 & & & \\
\hline Thinking about the students' & First & 3,732 & 0,84 & 3.854 & 4 & 0.005 \\
\hline
\end{tabular}




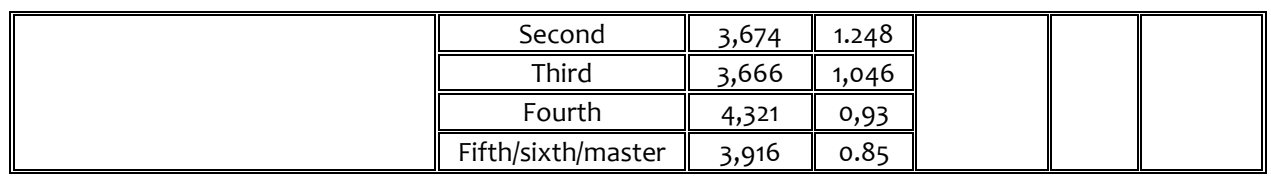

Table 6 shows the items with statistically significant differences in the students' perceptions of reflective practice as a changing factor of the teaching performance considering the year of studies $(p<0.005)$. The greatest difference in the students' answers appears regarding the last item, and it concerns students of the third year of studies $(M=3.666)$ who generally answered I neither agree, nor disagree and the students of the fourth year of studies $(M=4.321)$ who mostly answered I agree. The obtained data shows us that the students agree that reflective practice is important for the quality teaching and its quality performance, and, based on that, we can confirm the hypothesis that 'It is assumed that the students think that reflective practice improves teaching performance'.

Table 7 - The differences in the students' perceptions of reflective practice as a changing factor of the teaching guidance and course considering the faculty

\begin{tabular}{|c|c|c|c|c|c|c|}
\hline & Faculty & $\mathbf{M}$ & SD & F-test & df & $\mathrm{p}$ \\
\hline \multirow{3}{*}{$\begin{array}{l}\text { The professor must be } \\
\text { open for trying new ways } \\
\text { of working than those } \\
\text { already established which } \\
\text { maintain students' } \\
\text { attention, interest and } \\
\text { activity }\end{array}$} & $\begin{array}{l}\text { Faculty of natural } \\
\text { sciences }\end{array}$ & 4.148 & 1.167 & \multirow{3}{*}{10.049} & \multirow{3}{*}{2} & \multirow{3}{*}{0.000} \\
\hline & $\begin{array}{l}\text { Faculty of social and } \\
\text { humanistic sciences }\end{array}$ & 4.636 & 0.562 & & & \\
\hline & Technical faculty & 4.118 & 0.923 & & & \\
\hline \multirow{3}{*}{$\begin{array}{l}\text { If the teaching was } \\
\text { unsuccessful, it is } \\
\text { important for the teacher } \\
\text { to ask himself what led to } \\
\text { such outcome, in order to } \\
\text { improve his work in the } \\
\text { future }\end{array}$} & $\begin{array}{c}\text { Faculty of natural } \\
\text { sciences }\end{array}$ & 4.556 & 0.751 & \multirow{3}{*}{6.975} & \multirow{3}{*}{2} & \multirow{3}{*}{0.001} \\
\hline & $\begin{array}{l}\text { Faculty of social and } \\
\text { humanistic sciences }\end{array}$ & 4.646 & 0.594 & & & \\
\hline & Technical faculty & 4.224 & 0.918 & & & \\
\hline \multirow{3}{*}{$\begin{array}{l}\text { If the teaching was } \\
\text { successful, it is important } \\
\text { for the teacher to ask } \\
\text { himself what led to such } \\
\text { outcome, in order to } \\
\text { improve his work in the } \\
\text { future }\end{array}$} & $\begin{array}{l}\text { Faculty of natural } \\
\text { sciences }\end{array}$ & 4.481 & 0.700 & \multirow{3}{*}{12.828} & \multirow{3}{*}{2} & \multirow{3}{*}{0.000} \\
\hline & $\begin{array}{l}\text { Faculty of social and } \\
\text { humanistic sciences }\end{array}$ & 4.545 & 0.627 & & & \\
\hline & Technical faculty & 3.934 & 1.037 & & & \\
\hline \multirow{3}{*}{$\begin{array}{l}\text { Conducting the research } \\
\text { with the aim of } \\
\text { understanding his } \\
\text { students' needs enables } \\
\text { the professor to adjust the } \\
\text { rhythm and the course of } \\
\text { teaching }\end{array}$} & $\begin{array}{c}\text { Faculty of natural } \\
\text { sciences }\end{array}$ & 3.777 & 1.086 & \multirow{3}{*}{7.715} & \multirow{3}{*}{2} & \multirow{3}{*}{0.001} \\
\hline & $\begin{array}{l}\text { Faculty of social and } \\
\text { humanistic sciences }\end{array}$ & 4.303 & 0.775 & & & \\
\hline & Technical faculty & 3.842 & 0.895 & & & \\
\hline
\end{tabular}


Table 7 shows the items with statistically significant differences in the students' perceptions of reflective practice as a changing factor of the teaching guidance and course considering the faculty, taken the value of $p<0.005(p=0.000 ; p=0.001 ; p=0.000$ and $p=0.001)$. The students of social and humanistic sciences show the highest degree of agreement in their answers to the presented items $(M=4.636 ; M=4.646 ; M=4.545 ; M=4.303)$. These students have mostly given the answer I agree. The students of the technical faculty have been indecisive, because their answer to the second to last and to the last item was I neither agree nor disagree $(M=3.934$; $M=3.842)$.

Table 8 - The differences in the students' perceptions of reflective practice as a changing factor of the teaching guidance and course considering the year of studies

\begin{tabular}{|c|c|c|c|c|c|c|}
\hline & Year of studies & M & SD & F-test & df & p \\
\hline \multirow{5}{*}{$\begin{array}{l}\text { The professor must be open } \\
\text { for trying new ways of } \\
\text { working Instead of those } \\
\text { already established which } \\
\text { maintain students' } \\
\text { attention, interest and } \\
\text { activity }\end{array}$} & First & 4.072 & 0.951 & \multirow{5}{*}{5.129} & \multirow{5}{*}{4} & \multirow{5}{*}{0.001} \\
\hline & Second & 4.233 & 1.065 & & & \\
\hline & Third & 4.267 & 0.798 & & & \\
\hline & Fourth & 4.594 & 0.559 & & & \\
\hline & Fifth/sixth/master & 4.694 & 0.502 & & & \\
\hline \multirow{5}{*}{$\begin{array}{l}\text { If the teaching was } \\
\text { unsuccessful, it is important } \\
\text { for the teacher to ask } \\
\text { himself what led to such } \\
\text { outcome, in order to } \\
\text { improve his work in the } \\
\text { future }\end{array}$} & First & 4.089 & 1.014 & \multirow{5}{*}{6.135} & \multirow{5}{*}{4} & \multirow{5}{*}{0.000} \\
\hline & Second & 4.674 & 0.522 & & & \\
\hline & Third & 4.333 & 0.899 & & & \\
\hline & Fourth & 4.562 & 0.669 & & & \\
\hline & Fifth/sixth/master & 4.696 & 0.502 & & & \\
\hline \multirow{5}{*}{$\begin{array}{l}\text { If the teaching was } \\
\text { successful, it is important } \\
\text { for the teacher to ask } \\
\text { himself what led to such } \\
\text { outcome, in order to } \\
\text { improve his work in the } \\
\text { future }\end{array}$} & First & 3.821 & 1.063 & \multirow{5}{*}{7.878} & \multirow{5}{*}{4} & \multirow{5}{*}{0.000} \\
\hline & Second & 4.372 & 0.787 & & & \\
\hline & Third & 4.267 & 0.798 & & & \\
\hline & Fourth & 4.562 & 0.619 & & & \\
\hline & Fifth/sixth/master & 4.607 & 0.593 & & & \\
\hline \multirow{5}{*}{$\begin{array}{l}\text { Conducting the research } \\
\text { with the aim of } \\
\text { understanding his students' } \\
\text { needs enables the professor } \\
\text { to adjust the rhythm and the } \\
\text { course of teaching to them }\end{array}$} & First & 3.678 & 0.955 & \multirow{5}{*}{4.414} & \multirow{5}{*}{4} & \multirow{5}{*}{0.002} \\
\hline & Second & 4.023 & 0.912 & & & \\
\hline & Third & 4.267 & 0.704 & & & \\
\hline & Fourth & 4.281 & 0.772 & & & \\
\hline & Fifth/sixth/master & 4.059 & 0.896 & & & \\
\hline
\end{tabular}

Table 8 shows the items with statistically significant differences in the students' perceptions of reflective practice as a changing factor of the teaching guidance and course considering the year of studies, with the value $p=0.001 ; p=0.000 ; p=0.000$ and $p=0.002(p<0.005)$. The greatest difference in the students' answers appears in the second to the last item between the students of the first year of studies and the students of the fifth/sixth year/master studies 
$(M=3.821$ and $M=4.607)$ as well as in the last item between the students of the first year of studies and the students of the fourth year of studies $(M=3.678$ and $M=4.281)$. The majority of students see reflective practice as an important factor of changing the teaching quality, so we can confirm the hypothesis that 'It is assumed that the students think that reflective practice improves the teaching guidance and course'. As Bandur and Maksimovic (2013) state, reflective practice is insecure and full of conflicts, and so, continuous reflection and verification based on thinking, recognizing and testing the implicit pedagogy, hypothesis and previous experiences in the current circumstances are highlighted as an important requirement that needs to be practically realized. This is confirmed with the results obtained, because teacher's working experience in the past is the basis for improving his work in the future. Realizing the advantages and the flaws of his own work can help the teacher to change the negative, and to retain and develop the positive elements of teaching while planning his future work.

Table 9 - The differences in the students' perceptions of reflective practice as a changing factor of the classroom climate considering the faculty

\begin{tabular}{|c|c|c|c|c|c|c|}
\hline & Faculty & M & SD & F-test & df & $\mathrm{p}$ \\
\hline \multirow{3}{*}{$\begin{array}{l}\text { Re-examining his own } \\
\text { prejudices helps the } \\
\text { professor to reduce } \\
\text { inappropriate } \\
\text { reactions based on } \\
\text { students' race, gender, } \\
\text { culture or social status }\end{array}$} & $\begin{array}{l}\text { Faculty of natural } \\
\text { sciences }\end{array}$ & 3.926 & 1.035 & \multirow{3}{*}{4.574} & \multirow{3}{*}{2} & \multirow{3}{*}{0.011} \\
\hline & $\begin{array}{l}\text { Faculty of social and } \\
\text { humanistic sciences }\end{array}$ & 4.293 & 0.917 & & & \\
\hline & Technical faculty & 3.882 & 0.937 & & & \\
\hline \multirow{3}{*}{$\begin{array}{l}\text { In order to motivate } \\
\text { students and to } \\
\text { develop their positive } \\
\text { attitudes towards } \\
\text { teaching, the professor } \\
\text { has to show openness } \\
\text { for trying new } \\
\text { methods of working }\end{array}$} & $\begin{array}{l}\text { Faculty of natural } \\
\text { sciences }\end{array}$ & 4.259 & 0.764 & \multirow{3}{*}{$13 \cdot 361$} & \multirow{3}{*}{2} & \multirow{3}{*}{$\begin{array}{c}0.00 \\
0\end{array}$} \\
\hline & $\begin{array}{l}\text { Faculty of social and } \\
\text { humanistic sciences }\end{array}$ & 4.606 & 0.531 & & & \\
\hline & Technical faculty & 4.000 & 1.006 & & & \\
\hline
\end{tabular}

Table 9 demonstrates the items with statistically significant differences in the students' perceptions of reflective practice as a changing factor of the classroom climate considering the faculty, with the value $p<0.005(p=0.011$ and $p=0.000)$. We can observe the difference in attitudes between social and humanistic sciences students and technical sciences students within both items presented $(M=4.293 ; M=3.882$ for the first item and $M=4.606 ; M=4.00$ for the second item).

Table 10 - The differences in the students' perceptions of reflective practice as a changing factor of the classroom climate considering the year of studies

\begin{tabular}{|c|c|c|c|c|c|c|}
\hline & Year of studies & $\mathbf{M}$ & SD & F-test & df & p \\
\hline \multirow{4}{*}{$\begin{array}{l}\text { Discussions between the } \\
\text { professor and the } \\
\text { students contribute to the } \\
\text { development of mutual }\end{array}$} & First & 4.214 & 0.888 & \multirow[t]{4}{*}{2.748} & \multirow[t]{4}{*}{4} & \multirow[t]{4}{*}{0.030} \\
\hline & Second & 4.581 & 0.794 & & & \\
\hline & Third & 4.333 & 0.488 & & & \\
\hline & Fourth & 4.625 & 0.707 & & & \\
\hline
\end{tabular}




\begin{tabular}{|c|c|c|c|c|c|c|}
\hline & Fifth/sixth/master & 4.589 & 0.596 & & & \\
\hline \multirow{5}{*}{$\begin{array}{l}\text { Re-examining his own } \\
\text { prejudices helps the } \\
\text { professor to reduce } \\
\text { inappropriate reactions } \\
\text { based on students' race, } \\
\text { gender, culture or social } \\
\text { status }\end{array}$} & First & 3.786 & 1.004 & \multirow{5}{*}{2.939} & \multirow{5}{*}{4} & \multirow{5}{*}{0.022} \\
\hline & Second & 4.116 & 0.851 & & & \\
\hline & Third & 4.067 & 0.798 & & & \\
\hline & Fourth & 4.062 & 1.105 & & & \\
\hline & Fifth/sixth/master & 4.393 & 0.867 & & & \\
\hline \multirow{5}{*}{$\begin{array}{l}\text { In order to motivate } \\
\text { students and to develop } \\
\text { their positive attitudes } \\
\text { towards teaching, the } \\
\text { professor has to show } \\
\text { openness for trying new } \\
\text { methods of working }\end{array}$} & First & 3.893 & 0.966 & \multirow{5}{*}{8.263} & \multirow{5}{*}{4} & \multirow{5}{*}{0.000} \\
\hline & Second & 4.302 & 0.860 & & & \\
\hline & Third & 4.733 & 0.594 & & & \\
\hline & Fourth & 4.375 & 0.659 & & & \\
\hline & Fifth/sixth/master & 4.332 & 0.514 & & & \\
\hline
\end{tabular}

The items with the statistically significant differences in the students' perceptions of reflective practice as a changing factor of the classroom climate considering the year of studies $(p<0.005)$ are shown in Table 10. The greatest difference in students' attitudes appears within the last item between the students of the first year of studies, with a general answer I neither agree, nor disagree and between the students of the fifth/sixth year of studies/master studies who predominantly answered I agree $(M=3.893$ and $M=4.733)$. Bard (2014) said that the students freely exchange their opinions on lessons and activities amongst themselves, but they usually do not talk about this with their teachers. When they feel that they do not have any reason to fear, and that they can contribute to finding the meaning and the productivity of the class, they discuss, carefully choosing the words in order not to hurt teacher's feelings. The obtained results support such opinion, because students think that the discussions with their professors are crucial for the development of mutual respect, understanding and reconciliation of mutual reactions, by getting rid of their prejudices and by opening themselves to new, different ways of working, which automatically implies the improvement of the classroom climate. Regardless of the faculty and year of studies, students think that reflective practice contributes to the improvement of the classroom climate, which confirms the hypothesis that 'It is assumed that students think that reflective practice improves the classroom climate'.

Table 11 - The differences in the students' perceptions of reflective practice as a changing factor of the discipline during class considering the faculty

\begin{tabular}{|c|c|c|c|c|c|c|}
\hline & Faculty & $\mathbf{M}$ & SD & F-test & df & p \\
\hline \multirow{3}{*}{$\begin{array}{l}\text { It is useful for the } \\
\text { professor to think } \\
\text { about the ways he can } \\
\text { provide and maintain } \\
\text { the discipline during } \\
\text { class }\end{array}$} & Faculty of natural sciences & 4,333 & 0,784 & \multirow{3}{*}{5,309} & \multirow{3}{*}{2} & \multirow{3}{*}{0,006} \\
\hline & $\begin{array}{l}\text { Faculty of social and } \\
\text { humanistic sciences }\end{array}$ & 4,444 & 0,658 & & & \\
\hline & Technical faculty & 4,092 & 0,751 & & & \\
\hline $\begin{array}{l}\text { It is important for the } \\
\text { professor to ask }\end{array}$ & Faculty of natural sciences & 4,111 & 1,050 & 4,807 & 2 & 0,009 \\
\hline
\end{tabular}




\begin{tabular}{|c|c|c|c|c|c|c|}
\hline & $\begin{array}{l}\text { Faculty of social and } \\
\text { humanistic sciences }\end{array}$ & 4,414 & $\begin{array}{c}0,93 \\
7\end{array}$ & & & \\
\hline & Technical faculty & 4,026 & $\begin{array}{c}0,93 \\
7\end{array}$ & & & \\
\hline \multirow{3}{*}{$\begin{array}{l}\text { If the students disturb } \\
\text { the teaching, the } \\
\text { professor has to } \\
\text { wonder about the } \\
\text { cause of such actions }\end{array}$} & Faculty of natural sciences & 3,815 & 1,331 & \multirow{3}{*}{4,459} & \multirow{3}{*}{2} & \multirow{3}{*}{0,013} \\
\hline & $\begin{array}{l}\text { Faculty of social and } \\
\text { humanistic sciences }\end{array}$ & 4,162 & 0,817 & & & \\
\hline & Technical faculty & 3,710 & 1,129 & & & \\
\hline
\end{tabular}

Table 11 presents the items that show statistically significant differences in students' perceptions of reflective practice as a changing factor of the discipline during class considering the faculty. The greatest difference in students' attitudes is notable in the last item. The social and humanistic sciences students' answers $(M=4.162)$, that were mostly I agree, differ from the natural sciences students' answers $(M=3.815)$ and from the technical sciences students' answers $(M=3.710)$, which were indecisive.

Table 12 - The differences in the students' perceptions of reflective practice as a changing factor of the discipline during class considering the year of studies

\begin{tabular}{|c|c|c|c|c|c|c|}
\hline & Year of studies & M & SD & F-test & df & p \\
\hline \multirow{5}{*}{$\begin{array}{l}\text { It is useful for the professor to } \\
\text { think about the ways he can } \\
\text { provide and maintain the } \\
\text { discipline during class }\end{array}$} & First & 3.964 & 0.808 & \multirow{5}{*}{4.637} & \multirow{5}{*}{4} & \multirow{5}{*}{0.001} \\
\hline & Second & 4.418 & 0.663 & & & \\
\hline & Third & 4.267 & 0.703 & & & \\
\hline & Fourth & 4.500 & 0.568 & & & \\
\hline & Fifth/sixth/master & 4.428 & 0.684 & & & \\
\hline \multirow{5}{*}{$\begin{array}{l}\text { It is important for the professor to } \\
\text { ask himself - How can I react to } \\
\text { rude behaviour and disobedience } \\
\text { in the classroom }\end{array}$} & First & 3.875 & 1.010 & \multirow{5}{*}{4.654} & \multirow{5}{*}{4} & \multirow{5}{*}{0.001} \\
\hline & Second & 4.279 & 0.854 & & & \\
\hline & Third & 4.000 & 1.000 & & & \\
\hline & Fourth & 4.500 & 0.672 & & & \\
\hline & Fifth/sixth/master & 4.446 & 0.630 & & & \\
\hline \multirow{5}{*}{$\begin{array}{l}\text { If the students disturb the } \\
\text { teaching, the professor has to } \\
\text { wonder about the cause of such } \\
\text { actions }\end{array}$} & First & 3.625 & 1.105 & \multirow{5}{*}{$5 \cdot 381$} & \multirow{5}{*}{4} & \multirow{5}{*}{0.000} \\
\hline & Second & 3.767 & 1.192 & & & \\
\hline & Third & 3.533 & 1.356 & & & \\
\hline & Fourth & 4.250 & 0.803 & & & \\
\hline & Fifth/sixth/master & 4.339 & 0.640 & & & \\
\hline \multirow{5}{*}{$\begin{array}{l}\text { The professor must be ready to } \\
\text { perceive things from the student's } \\
\text { perspective in order to react in an } \\
\text { adequate way }\end{array}$} & First & 4.125 & 0.935 & \multirow{5}{*}{4.219} & \multirow{5}{*}{4} & \multirow{5}{*}{0.003} \\
\hline & Second & 4.163 & 1.022 & & & \\
\hline & Third & 3.533 & 0.990 & & & \\
\hline & $\begin{array}{l}\text { Fourth } \\
\end{array}$ & 4.344 & 0.787 & & & \\
\hline & Fifth/sixth/master & 4.500 & 0.632 & & & \\
\hline
\end{tabular}


The items that show statistically significant differences in the students' perceptions of reflective practice as a changing factor of the discipline during class considering the year of studies $(p<0.005)$ are listed in Table 12. For the first item, the greatest difference in the students' answers appears between the students of the first year of studies and the students of the fourth year of studies $(M=3.964 ; M=4.500)$, for the second item also between the students of the first year of studies and the students of the fourth year of studies $(M=3.875$; $M=4.500$ ), for the third item between the students of the third year of studies and the students of the fifth/sixth year of studies/master studies $(M=3.533 ; M=4.339)$, and for the fourth item between the students of the third year of studies and the students of the fifth/sixth year of studies/master studies $(M=3.533 ; M=4.500)$. Obtained results indicate that the majority of students agree and totally agree that the professor's reflective practice can contribute to the improvement of the discipline during class, which confirms the hypothesis that 'It is assumed that students think that reflective practice improves the discipline during class.' These findings confirm the views expressed by Larrivee (2000), who states that being successful in a modern classroom does not mean to simply apply the teaching management techniques, and to ensure that the students work on their tasks and maintain good behaviour. The success requires the teacher's mobility and readiness for responding in every situation. When a teacher becomes a reflective practitioner, he has the ability to integrate and to modify skills according to the contextual requirements, and also to create new strategies. He develops a sense of self-efficiency which enables him to find solutions.

Table 13 - The differences in the students' perceptions of reflective practice as a changing factor of the evaluation of students' progress and self-evaluation considering the faculty

\begin{tabular}{|c|c|c|c|c|c|c|}
\hline & Faculty & M & SD & F-test & df & p \\
\hline \multirow{3}{*}{$\begin{array}{c}\text { When evaluating the students' } \\
\text { progress, it is important that the } \\
\text { professor identifies the } \\
\text { problems and the difficulties } \\
\text { they are facing while studying }\end{array}$} & $\begin{array}{l}\text { Faculty of natural } \\
\text { sciences }\end{array}$ & 3.889 & 1.311 & \multirow{3}{*}{5.941} & \multirow{3}{*}{2} & \multirow{3}{*}{0.003} \\
\hline & $\begin{array}{l}\text { Faculty of social and } \\
\text { humanistic sciences }\end{array}$ & 4.384 & 0.752 & & & \\
\hline & Technical faculty & 3.934 & 1.037 & & & \\
\hline \multirow{3}{*}{$\begin{array}{l}\text { When evaluating the students, } \\
\text { the professor gets an insight into } \\
\text { how successful the teaching was }\end{array}$} & $\begin{array}{l}\text { Faculty of natural } \\
\text { sciences }\end{array}$ & 3.518 & 1.341 & \multirow{3}{*}{3.646} & \multirow{3}{*}{2} & \multirow{3}{*}{0.028} \\
\hline & $\begin{array}{l}\text { Faculty of social and } \\
\text { humanistic sciences }\end{array}$ & 4.071 & 0.836 & & & \\
\hline & Technical faculty & 3.816 & 1.067 & & & \\
\hline \multirow{3}{*}{$\begin{array}{l}\text { The teaching quality is based on } \\
\text { the professor's continuous self- } \\
\text { analysis and self-monitoring }\end{array}$} & $\begin{array}{l}\text { Faculty of natural } \\
\text { sciences }\end{array}$ & 4.111 & 0.751 & \multirow{3}{*}{7.000} & \multirow{3}{*}{2} & \multirow{3}{*}{0.001} \\
\hline & $\begin{array}{l}\text { Faculty of social and } \\
\text { humanistic sciences }\end{array}$ & 4.364 & 0.762 & & & \\
\hline & Technical faculty & 3.908 & 0.867 & & & \\
\hline $\begin{array}{l}\text { It is necessary for the professor } \\
\text { to regularly reflect on his own } \\
\text { work in order to see what needs }\end{array}$ & $\begin{array}{l}\text { Faculty of natural } \\
\text { sciences }\end{array}$ & 3.963 & 1.250 & 7.650 & 2 & 0.001 \\
\hline
\end{tabular}




\begin{tabular}{|c|c|c|c|c|c|c|}
\hline & $\begin{array}{l}\text { Faculty of social and } \\
\text { humanistic sciences }\end{array}$ & 4.475 & 0.659 & & & \\
\hline & Technical faculty & 4.013 & 0.892 & & & \\
\hline \multirow{3}{*}{$\begin{array}{c}\text { It is useful for the professor to } \\
\text { regularly reflect on how to make } \\
\text { a better use of his time and } \\
\text { effort }\end{array}$} & $\begin{array}{l}\text { Faculty of natural } \\
\text { sciences }\end{array}$ & 3.778 & 1.121 & \multirow{3}{*}{11.342} & \multirow{3}{*}{2} & \multirow{3}{*}{0.000} \\
\hline & $\begin{array}{l}\text { Faculty of social and } \\
\text { humanistic sciences }\end{array}$ & 4.444 & 0.703 & & & \\
\hline & Technical faculty & 3.947 & 0.847 & & & \\
\hline
\end{tabular}

The Table 13 shows the differences in the students' perceptions of reflective practice as a changing factor of the evaluation of students' progress and self-evaluation considering the faculty. The statistically significant difference was determined for each item, since the value $p<0.005(p=0.003 ; p=0.028 ; p=0.001 ; p=0.001$ and $p=0.000)$. The students of social and humanistic sciences show the highest level of agreement in the answers to the presented items ( $M=4.384 ; M=4.071 ; M=4.363 ; M=4.475 ; M=4.444)$, with a general I agree answer.

Table 14 - The differences in the students' perceptions of reflective practice as a changing factor of the evaluation of students' progress and self-evaluation considering the year of studies

\begin{tabular}{|c|c|c|c|c|c|c|}
\hline & Year of studies & $M$ & SD & F-test & df & $\mathbf{p}$ \\
\hline \multirow{5}{*}{$\begin{array}{l}\text { When evaluating the students' } \\
\text { progress, it is important that the } \\
\text { professor identifies the problems } \\
\text { and the difficulties they are facing } \\
\text { while studying }\end{array}$} & First & 3.821 & 0.936 & \multirow{5}{*}{5.541} & \multirow{5}{*}{4} & \multirow{5}{*}{0.000} \\
\hline & Second & 4.186 & 1.180 & & & \\
\hline & Third & 3.533 & 1.130 & & & \\
\hline & Fourth & 4.437 & 0,669 & & & \\
\hline & Fifth/sixth/master & 4.446 & 0.711 & & & \\
\hline \multirow{5}{*}{$\begin{array}{l}\text { The teaching quality is based on } \\
\text { the professor's continuous self- } \\
\text { analysis and self-monitoring }\end{array}$} & First & 3.786 & 0.868 & \multirow{5}{*}{5.062} & \multirow{5}{*}{4} & \multirow{5}{*}{0.001} \\
\hline & Second & 4.279 & 0.735 & & & \\
\hline & Third & 4.000 & 0.845 & & & \\
\hline & Fourth & 4.437 & 0.801 & & & \\
\hline & Fifth/sixth/master & 4.321 & 0.741 & & & \\
\hline \multirow{5}{*}{$\begin{array}{l}\text { It is necessary for the professor to } \\
\text { regularly reflect on his own work in } \\
\text { order to see what needs to be } \\
\text { improved }\end{array}$} & First & 3.875 & 1.028 & \multirow{5}{*}{3.769} & \multirow{5}{*}{4} & \multirow{5}{*}{0.006} \\
\hline & Second & 4.233 & 1.065 & & & \\
\hline & Third & 4.333 & 0.724 & & & \\
\hline & Fourth & 4.500 & 0.622 & & & \\
\hline & $\begin{array}{l}\text { Fifth/sixth/master } \\
\end{array}$ & 4.411 & 0.654 & & & \\
\hline \multirow{5}{*}{$\begin{array}{l}\text { It is useful for the professor to } \\
\text { regularly reflect on how to make a } \\
\text { better use of his time and effort }\end{array}$} & First & 3.839 & 0.910 & \multirow{5}{*}{3.827} & \multirow{5}{*}{4} & \multirow{5}{*}{0.005} \\
\hline & Second & 4.209 & 0.940 & & & \\
\hline & Third & 4.000 & 0.845 & & & \\
\hline & Fourth & 4.344 & 0.745 & & & \\
\hline & Fifth/sixth/master & 4.168 & 0.733 & & & \\
\hline
\end{tabular}

Table 14 presents the items that show statistically significant differences in the students' perceptions of reflective practice as a changing factor of the evaluation of students' progress 
and self-evaluation considering the year of studies $(p<0.005)$. For the first item, the greatest difference in the students' answers appears between the students of the third year of studies and the students of the fifth/sixth year of studies/master studies $(M=3.533 ; M=4.446)$, for the second item between the students of the first year of studies and the students of the fourth year of studies $(M=3.786 ; M=4.437)$, for the third item between the students of the first year of studies and the students of the fourth year of studies $(M=3.875 ; M=4.500)$, and for the fourth item also between the students of the first year of studies and the students of the fourth year of studies $(M=3.839 ; M=4.344)$. The obtained results show that the majority of students agree and totally agree that reflective practice represents an improving factor of the evaluation of students' progress and self-evaluation, and therefore confirms the hypothesis It is assumed that students think that reflective practice improves the evaluation of students' progress and self-evaluation.

\section{Conclusion and remarks}

In our educational system practice, it is still untypical for the teacher to work on the development of his reflective practice. However, a modern school requires a teacher reflective practitioner, because reflective practice represents a continuous re-examination of one's own work in order to improve it. The main aspects of reflective practice are: collaborating and exchanging the experiences with colleagues, discussions and exchange of information with students, researching the professional and scientific literature, getting over their own prejudices and stereotypes, conducting researches, keeping a diary, taking notes about their own work etc. These elements are in the focus of our research with the aim to find out which of them contribute to the change of teaching quality, presented through teaching skills (planning and preparation of the teaching, its performance, guidance and course, classroom climate, discipline, evaluation of students' progress and self-evaluation). Our aim was to find out how students perceive their professors' practice, and whether they recognize some of the reflective elements as important for teaching quality improvement.

Based on the obtained results, we confirmed all hypothesis of the research, considering the fact that the students' answers on the research questions were usually I agree and I totally agree, regardless of the year of studies and the faculty. Lower number of respondents answered with I neither agree, nor disagree, and the lowest number answered with I do not agree and I do not agree at all. These results show great importance, since it means that the students do recognize which teachers' behaviour can lead to the change of teaching quality. Students have positive attitudes towards the elements of reflective practice as changing factors of teaching quality, considering that they recognised them as important for the improvement of the teaching process. Still, this doesn't mean that these elements are present in the teaching practice. Therefore, we state the examination of the elements of reflective practice in teaching, with the aim of showing its importance and contribution to the improvement of teaching quality, as our recommendation for the future researches. On the other hand, despite the fact that reflective practice has not yet taken the well-deserved position in our educational system, some teachers do behave as reflective practitioners, without being aware of it. Therefore, similar researches are needed in order to identify the elements of reflective practice in our educational system, which will help teachers to recognize themselves as practitioners who are on their way of becoming reflective. 


\section{References}

Akbari, R., Kiany G. R., Imani Naeeni M. I. N. \&Karimi Allvar, N. (2008). Teachers' Teaching Styles, Sense of Efficacy and Reflectivity as Correlates of Students' Achievement Outcomes, IJAL, 11 (1), 1-28.

Bandur, V. \& Maksimovic, J. (2013). The Teacher - A Reflective Researcher of the Teaching Practice, Croatian Journal of Education, 15 (3), 99-124.

Bard, R. (2014). Focus on Learning: Reflective Learners and Feedback, The Electronic Journal for English as a Second Language, 18(3), 1-18.

Bilac, S. (2015). Refleksivna praksa - cimbenik utjecaja na profesionalni razvoj, mijenjanje odgojno-obrazovne prakse i kvalitetu nastave, Napredak, 156 (4), 447-460.

Brookfield, S. D. (2005). Becoming a Critically Reflective Teacher. San Francisco: Jossey-Bass Publishers.

Budevac, N., Josic, S., Radisic, J., \&Baucal, A. (2013). Nastavnik kao refleksivni prakticar. Beograd: Ministarstvo prosvete, nauke i tehnoloskog razvoja Republike Srbije.

Harvey, M., Coulson, D., \& McMaugh, A. (2016). Towards a Theory of the Ecology of Reflection: Reflective Practice for Experiential Learning in Higher Education, Journal of University Teaching \& Learning Practice, 13 (2), 1-20.

Impedovo, M. A., \& Khatoon Malik, S. (2016). Becoming a Reflective In-service Teacher: Role of Research Attitude, Australian Journal of Teaching Education, 41 (1), 100-112.

Kayapinar, U. (2016). A Study on Reflection in In-Service Teacher Development: Introducing Reflective Practitioner Development Model, Educational Sciences: Theory \& Practice, 16 (5), 1671-1691.

Kyriacou, C. (2001). Temeljna nastavna umijeca. Zagreb: Educa.

Larrivee, B. (2000). Transforming Teaching Practice: Becoming the Critically Reflective Teacher, Reflective Practice, 1 (3), 293-307.

Mena Marcos, J. J., Sanchez Miguel, E., \& Tillema, H. (2009). Teacher Reflection on Action: What is Said (in Research) and what is done (in Teaching), Reflective Practice, 10 (2), 191-204.

Ryan, T. G. (2007). The Reflexive Classroom Manager: A Required Pre-Service Mode, Networks, $9(1), 1-6$.

Singh Gill, G. (2014). The Nature of Reflective Practice and Emotional Intelligence in Tutorial Settings, Journal of Education and Learning, 3 (1), 86-100.

Soisangwarn, A., \& S. Wongwanich (2014). Promoting the Reflective Teacher through Peer Coaching to Improve Teaching Skills, Procedia - Social and Behavioural Sciences, 116, 2504-2511.

Vijaua Kumari, S. N. (2014). Constructivist Approach to Teacher Education: An Integrative Model for Reflective Teaching, Journal on Educational Psychology, 7 (4), 31-40.

\section{Biographical notes:}

Dr Jelena Maksimovic (1977) is Associate Professor at the Department of Pedagogy, Faculty of Philosophy at University of Nis for the subject: Methodology of pedagogy and Research in pedagogy. She has published two monographs and six textbooks and more than 140 scientific papers in journals and conference proceedings. Science Field: Methodology of pedagogical research, Statistics in pedagogy, Action Research, Data Processing in educational research. 
Ma Jelena Osmanovic (1989) is teaching assistant at the Department of Pedagogy at the Faculty of Philosophy of the University of Nis and she is a student of doctoral studies in pedagogy. Scientific area: Methodology of pedagogical research, Research in pedagogy 